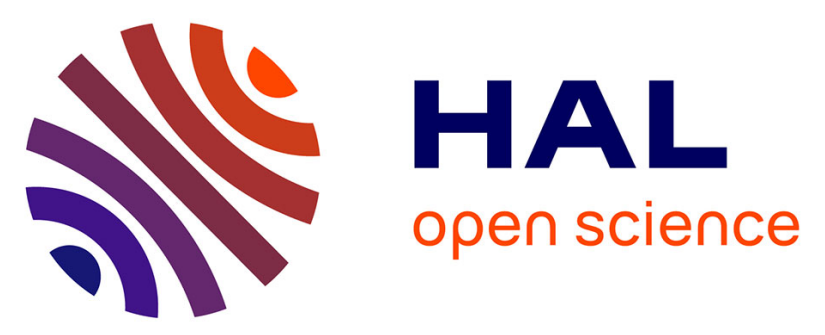

\title{
The Data from an Epidemiologic Study on the Insulin Resistance Syndrome Study: the change and the rate of change of the age-blood pressure relationship.
}

Michel E. Safar, Céline Lange, Jean Tichet, Jacques Blacher, Eveline Eschwège, Beverley Balkau, The Desir Study Group

\section{To cite this version:}

Michel E. Safar, Céline Lange, Jean Tichet, Jacques Blacher, Eveline Eschwège, et al.. The Data from an Epidemiologic Study on the Insulin Resistance Syndrome Study: the change and the rate of change of the age-blood pressure relationship.: Rate of change of the age-blood pressure relationship. Journal of Hypertension, 2008, 26 (10), pp.1903-11. 10.1097/HJH.0b013e32830b8937 . inserm-00292150

\section{HAL Id: inserm-00292150 https://www.hal.inserm.fr/inserm-00292150}

Submitted on 22 May 2014

HAL is a multi-disciplinary open access archive for the deposit and dissemination of scientific research documents, whether they are published or not. The documents may come from teaching and research institutions in France or abroad, or from public or private research centers.
L'archive ouverte pluridisciplinaire HAL, est destinée au dépôt et à la diffusion de documents scientifiques de niveau recherche, publiés ou non, émanant des établissements d'enseignement et de recherche français ou étrangers, des laboratoires publics ou privés. 


\title{
The D.E.S.I.R. study: the change and the rate of change of the age- blood pressure relationship.
}

\author{
Michel E Safar ${ }^{\mathrm{a}, \mathrm{b}}$, Céline Lange ${ }^{\mathrm{c}, \mathrm{d}}$, Jean Tichet $^{\mathrm{e}}$, Jacques Blacher ${ }^{\mathrm{a}, \mathrm{b}}$, \\ Eveline Eschwège ${ }^{\mathrm{c}, \mathrm{d}}$, Beverley Balkau ${ }^{\mathrm{c}, \mathrm{d}}$, and the D.E.S.I.R. Study Group ${ }^{\mathrm{e}}$ \\ ${ }^{\mathrm{a}}$ Paris-Descartes University, Faculty of Medicine, Hôtel-Dieu Hospital (MES, JB), F-75001 Paris, France; \\ b AP-HP, Diagnosis Center (MES, JB), F-75001 Paris, France; \\ ${ }^{\mathrm{c}}$ INSERM U780 (CL, EE, BB), Epidemiological and Biostatistical Research, F-94807 Villejuif, France ; \\ ${ }^{\mathrm{d}}$ Univ Paris-Sud (CL, EE, BB), IFR69, F-94807 Villejuif, France; \\ ${ }^{\mathrm{e}}$ Institut inter Régional pour la Santé (JT, D.E.S.I.R. Study Group), F-37521 La Riche, France.
}

Running title: Rate of change of the age-blood pressure relationship

\section{Correspondence to}

Beverley Balkau

INSERM U780

16 Ave Paul Vaillant-Couturier

F-94807 Villejuif, France

Tel.: 0033145595161

Fax: 0033147269454

Email: balkau@vjf.inserm.fr 


\begin{abstract}
Objective: Systolic and diastolic blood pressure (SBP and DBP) increase significantly until around 55 years, when SBP increases, DBP decreases. Whether the rates of change of SBP and DBP with age exhibit a similar dissociation has never been investigated.

Design and participants: D.E.S.I.R., a 9-year longitudinal study included 2,278 men and 2,314 women, 3065 years and SBP, DBP, and other cardio-metabolic risk factors were determined every three years. Results: Both SBP and DBP increased with age, more rapidly in women than in men. SBP and DBP were higher in the presence of risk factors (except smoking) but the increases with age were similar. For the rates of change, whereas $\triangle \mathrm{SBP}$ increased linearly with age, $\triangle \mathrm{DBP}$ declined as early as 45 years. This finding was not influenced by gender, menopause or other risk factors but was significantly attenuated in the presence of hypertension at baseline, whether treated or not, and mainly in men.

Conclusions: DBP increases with age between 30 and 60 years, $\triangle \mathrm{DBP}$ tends to be markedly reduced as early as 45 years, in contrast with $\triangle \mathrm{SBP}$. Consequences for the understanding of vascular aging and antihypertensive therapy remain to be explored.
\end{abstract}

\title{
Number of words: 191
}

Key words: Epidemiology, Age, Blood pressure 


\section{Introduction}

Antihypertensive therapy has considerably improved cardiovascular (CV) risk in people treated for hypertension $[\mathbf{1 , 2}]$.The major beneficial effect of $\mathrm{CV}$ prevention has been for stroke, congestive heart failure and renal insufficiency. Less progress has been made for the prevention of coronary heart disease. Despite an adequate drug treatment, a significant residual coronary risk is commonly observed during the long-term follow-up of hypertensive subjects [3]. Furthermore, a very particular haemodynamic pattern is frequently observed during antihypertensive therapy: while diastolic blood pressure (DBP) is adequately controlled ( $\leq 90 \mathrm{~mm} \mathrm{Hg}$ ), systolic blood pressure (SBP) remains frequently elevated above $140 \mathrm{~mm} \mathrm{Hg}$ [4]. This haemodynamic profile, which is commonly observed in the elderly, even in the total absence of antihypertensive drug treatment, is traditionally attributed to an age-induced increase in arterial stiffness together with the presence of altered wave reflections $[5,6]$. This observation suggests that, during chronic drug therapy, consistent interactions occur in the long term between aging, high SBP and/or DBP, and antihypertensive treatment. Such interactions are difficult to clarify because the duration of therapeutic trials approximates 3-5 years, while that of antihypertensive therapy is close to 30 years (and even longer). Taken together, these findings indicate the need to develop studies evaluating in parallel the changes of brachial SBP and DBP and the progressive development of vascular aging.

D.E.S.I.R. (Data from an Epidemiologic Study on the Insulin Resistance syndrome) is a cohort of more than 4,500 men and women aged 30-65 years at inclusion, who were investigated every 3 years for a total of 9 years follow-up [7]. From this long-term survey, it is possible to evaluate not only the mean values of SBP and DBP with age, but also the rate of change of this classical relationship, i.e. the change in SBP or DBP per unit year ( $\triangle \mathrm{SBP}$ or $\triangle \mathrm{DBP})$, in each gender, according to age at baseline. From the present D.E.S.I.R. study and other investigations [7-12], we know that the mean values of SBP and DBP increase progressively with age but also that, above 50-60 years of age, mean values of SBP increase with age while mean values of $\mathrm{DBP}$ begin to lower. Our working hypothesis is that the evolution of $\triangle \mathrm{SBP}$ and $\triangle \mathrm{DBP}$ also differ consistently, particularly $\triangle \mathrm{DBP}$, and that this process might influence the effects of drug treatment. 
The role of major cardiovascular risk factors such as smoking, blood pressure (BP), body weight, plasma cholesterol and glucose was systematically investigated.

\section{Methods}

\section{Participants}

The main objective of the 9-year longitudinal study D.E.S.I.R., was to clarify the development of the insulin resistance syndrome. It is not a population based study, but a study of individuals who volunteered for a heath check-up and who were willing to participate in a 9-year study. Participants were recruited over the period 1994 to 1998 from ten Health Examination Centres from volunteers insured by the French Social Security system, which offers periodic health examinations free of charge: $85 \%$ of the French population is eligible for these examinations [7]. The total population in the geographical area of our study was over four million inhabitants, and 90,000 individuals benefit from such examinations each year.. The protocol was approved by the CCPPRB (“Comité Consultatif de la Protection des Personnes pour la Recherche Biomédicale”) of Bicêtre Hospital, Paris, and participants signed an informed consent.

The analysis included 2,278 men and 2,314 women, aged 30 to 65 years, with measures at baseline for all studied parameters and at least one other measure of BP at one of the follow-up examinations at 3, 6 and 9 years after inclusion.

\section{Measures}

Arterial blood pressures were measured in a supine position after 5 minutes rest. Both at inclusion and at the 3-year follow-up examination, a mercury sphygmomanometer was used and at the 6- and 9-year examinations, an OMRON HEM-705CP. According to the validation study by O'Brien et al. [13] the OMRON HEM-705O device measures SBP $2 \mathrm{mmHg}$ and DBP $1 \mathrm{mmHg}$ lower than a standard mercury sphygmomanometer; we added these differences to the Omron measured blood pressures. Participants were lightly clad, and weight and height were measured, and body mass index $\left(\mathrm{BMI}=\right.$ weight $\left./ \mathrm{height}^{2}\left(\mathrm{~kg} / \mathrm{m}^{2}\right)\right)$ 
calculated. The waist was measured as the smallest circumference between the lower ribs and the iliac crest. Hypertensive treatment and hormone replacement therapy were recorded.

All biochemical measurements were from one of four health-centre biological laboratories located in France at Blois, Chartres, La Riche or Orléans. Total cholesterol, HDL-cholesterol and triglycerides, were assayed by DAX 24 (Bayer Diagnostics, Puteaux, France) or KONE (Evry, France). The fasting plasma glucose, measured by the glucose-oxidase method, was applied to fluoro-oxalated plasma using a Technicon RA1000 (Bayer Diagnostics, Puteaux, France) or a Specific or a Delta device (Konelab, Evry, France). The inter-laboratory variability was assessed monthly on normal and pathological values for each biologic variable, the coefficients of variation for laboratories being lower than $6 \%$ over the inclusion period.

The examining physician noted the menopausal status of the women at each of the four examinations: no hormonal tests to validate this status were carried out. The information was inconsistent for some of the women, so that we were able to class only 2,202 of the 2,314 women: 878 were postmenopausal at entry into the study, 575 were menopaused during the study, and 749 were premenopausal at the end of the nineyear follow-up. Hormone replacement therapy was taken by 853 women, of whom 361 were postmenopausal: 69 women did not provide information about hormonal replacement therapy.

Cardio-metabolic risk factors were defined as follows [14]:

- Overweight: $\mathrm{BMI} \geq 25 \mathrm{~kg} / \mathrm{m}^{2}$;

- Abdominal obesity: waist circumference $>102$ / 88 cm, men/women;

- $\quad$ High blood pressure: $\mathrm{SBP} \geq 130 \mathrm{mmHg}$ and/or DBP $\geq 85 \mathrm{mmHg}$;

- Smoker: current smoker;

- Hyper-cholesterolaemia: cholesterol: $\geq 5.70 \mathrm{mmol} / \mathrm{l}$;

- Hyper-triglyceridaemia: triglycerides $\geq 1.69 \mathrm{mmol} / \mathrm{l}$;

- Hypo-HDL-cholesterolaemia: HDL-cholesterol < 1.04 / 1.29 mmol/l, men/women; 
Glucose status (diabetic: treated or fasting plasma glucose $\geq 7.0 \mathrm{mmol} / \mathrm{l}$, impaired fasting glucose: fasting plasma glucose between 6.1 and $6.9 \mathrm{mmol} / 1$, normal: fasting plasma glucose $<6.1 \mathrm{mmol} / 1$.)

\section{Statistical methods}

The characteristics of the individuals, their SBP, DBP are presented at inclusion in the study, according to sex, by means (standard deviations) and percentages. We studied, the SBP and DBP of each individual, over the 9 years of follow-up, by two metrics: their values at baseline, and their rate of change per year, $\Delta \mathrm{SBP}, \Delta \mathrm{DBP}$, assuming a linear relation over the time period.

The relations between baseline SBP and DBP mean values and age, called "SBP and DBP mean values", were modelled by linear regression with respect to baseline age (as a continuous parameter) [11], and likelihood ratio tests determined whether these relations were better described by a linear or a curvilinear relation with age, by the addition of a squared term in age. These relations are shown graphically, with the observed data as points on the graphs by 5-year age groups, along with the modelled curve. We compared the relations between men and women, using likelihood ratio tests and present the regression relations with a) separate curves or lines, or with b) a combined curve or line if they did not differ significantly according to sex. These relations were also studied according to strata of cardio-metabolic risk factors, presence of anti-hypertensive drug treatment, menopausal status and hormone replacement therapy. For the different classes of antihypertensive agents, the numbers treated were too small to allow an adequate statistical evaluation (Table 1).

The changes per year in SBP and DBP were studied according to age at entry into the study, and by sex. For each subject a slope, or a change per year, was calculated for SBP and DBP over the nine years of the study, called " $\triangle \mathrm{SBP}$ ” and " $\triangle \mathrm{DBP}$ ". These values are shown graphically by 5-year age groups and modelled by regression analysis, according to age at entry into the cohort, with tests for linearity in age. These relations are shown graphically. We compared the relations between men and women using likelihood ratio tests and present models with a) separate curves or lines, or with b) a combined curve or line if they did not 
differ according to sex. These relations were also studied according to strata of cardio-metabolic risk factors and other factors indicated above.

A change in the intercept without any change in slope indicated a shift of the curve. A change in the slope indicated a change in the sensitivity of the system.

Analyses used SAS Version 8.2 (SAS Institute Inc. Cary, NC USA).

\section{Results}

\section{General characteristics of the studied population}

Table 1 shows the mean value of clinical and biological parameters and their evolution per year, assuming a linear progression. For the same age, and a similar percentage of antihypertensive drug therapy, women had a significantly lower mean weight, height, waist circumference, SBP and DBP than men, but a higher mean heart rate. Changes per year in weight and waist circumference were higher in women than in men, but an opposite finding was observed for the changes per year in SBP and DBP. Changes in biological parameters slightly differed between men and women during the follow-up. Antihypertetnsive treatment was mainly with beta blockers and ACE inhibitors; at inclusion angiotensin receptor blockers were not available.

\section{Mean values of brachial SBP and DBP at inclusion by age and sex}

At each age range at inclusion, the mean SBP was lower in women than in men (Fig. 1A). However, both in men and women, SBP increased linearly and significantly with age, at a higher rate $(P<0.0001)$ and with a lower intercept $(P<0.0001)$ in women than in men. In women, this latter finding was even more pronounced in postmenpause than in the premenopause; women who became menopaused during the follow-up having the greatest increase (data not shown). For SBP, the same model was studied in populations divided according to values of cardio-metabolic risk factors (BMI, BP status, smoking, total cholesterol, glucose status as well as waist circumference, HDL-cholesterol, triglycerides, menopause (data not shown for the latter factors)). Higher intercepts (except with smoking) were noted in the presence of the 
risk factors, antihypertensive drug treatment and hormonal replacement therapy (Table 2). There was one other exception: when individuals were divided according to BP status, for men and women without high BP at inclusion, there was little variation in mean SBP with age (Fig. 2A); for men and for women with high BP the intercepts were higher, with almost identical SBP-age coefficients.

There was a significant increase in DBP with age (Fig. 1B), with lower values in women than in men at each age range. In men and women, the best model was curvilinear, with a significantly steeper slope with age in women than in men. These relations were little changed in the presence of other cardiovascular risk factors or according to menopause (Table 2): when one of these risk factors was increased, equations of the model generally did not change their slope but had a significantly higher intercept, except for smoking in men. This was also true for men and women with high and with low BP where there were similar relations between DBP and age (Table 2, Fig. 2B).

In summary, the mean values of SBP and DBP increased with age, both in men and women. The increase in SBP and DBP with age was steeper in women than in men, particularly in postmenopausal women. The model relating BP to age was linear for SBP and curvilinear for DBP. The presence of other cardiovascular risk factors changed little the slope with age but was associated with a consistent increase in the intercept, except for smoking. These conclusions held when account was taken of blood pressure treatment (Table 2).

\section{Mean change of SBP and DBP per year $(\triangle \mathrm{SBP}$ and $\triangle \mathrm{DBP})$ by age at inclusion and by sex}

Figure 3 shows the mean change per year of SBP, $\triangle \mathrm{SBP}$ (Fig. 3A), and of DBP, $\triangle \mathrm{DBP}$ (Fig. 3B), according to age and sex in the overall population.

For $\triangle \mathrm{SBP}$ in the total population (Fig. 3A), the mean change per year increased significantly with age, with higher values $(P<0.0001)$ in men than in women. There was a similar slightly curvilinear model $(P<0.05)$ in both sexes with the increase being less pronounced at higher ages. The presence of the factors cited above did not modify this description (Table 3), and there was no longer a significant curvature when the population was divided according to these strata, with an exception regarding BP status. For men with 
or without high $\mathrm{BP}$ at inclusion, there was an increase in $\triangle \mathrm{SBP}$ with age of $0.4 \mathrm{mmHg}$ per 10 years of age, with a similar increase for women (Table 3). However, men and women with high BP had respectively, a yearly change 0.82 and $0.89 \mathrm{mmHg}$ lower than those without high $\mathrm{BP}$ at inclusion.

The $\triangle \mathrm{DBP}$ by age model exhibited a very particular aspect (Fig. 3B), as it was identical and curvilinear for both men and women, with a maximum value around 45 years of age, after which $\triangle \mathrm{DBP}$ decreased with age, showing negative values, after the age of 60 years. The finding was unaffected by the presence of the various covariates (Table 3), with the exception of high BP. In all of these cases the $\triangle \mathrm{DBP}$ curves were separated, with the men and women at lower risk having a higher $\triangle \mathrm{DBP}$. The $\triangle \mathrm{DBP}$-age relation remained curvilinear only for the men. This result indicates that over 45 years of age, $\triangle \mathrm{DBP}$ is reduced more and more with increasing age, particularly in those with high BP at baseline.

In summary, the relation between age and $\triangle \mathrm{SBP}$ and $\triangle \mathrm{DBP}$ differed markedly, increasing with age for $\triangle \mathrm{SBP}$ and decreasing for $\triangle \mathrm{DBP}$. This latter observation was not influenced by sex, or other possible confounders, excepting for antihypertensive treatment in women (Table 3).

\section{Discussion}

This analysis of the D.E.S.I.R. study of 2,278 men and 2,314 women, was focused on the long term changes of SBP and DBP with age, between the ages of 30 and 65 years. While some participants were over 60 years at inclusion, D.E.S.I.R. did not include a "true" geriatric population. Indeed, it is well established in studies of CV epidemiology that around 55-60 years of age, the increase in SBP with age is associated with a progressive and consistent reduction of DBP with age [8-12]. In the present longitudinal study (Fig. 1A and B), we showed that both the mean values of SBP and DBP increased markedly with age-class and were influenced by sex, menopausal status and metabolic disorders (cholesterol, glycaemia, obesity, ...). All these factors are usually associated with a shift of SBP and DBP toward higher BP values at each given age range. However, from the long term follow-up of D.E.S.I.R., another important factor 
was shown for the first time: the rate of change in SBP or DBP per year with age differed markedly for each of the two parameters. This rate increased progressively as function of age for SBP, but in contrast, decreased significantly with age for DBP, as soon as the age of 40-45 years had been reached. Thereafter, the rate of change of DBP per year decreased progressively and markedly with increasing age. This finding was independent of sex, menopausal status and increased levels of BMI, waist circumference, plasma cholesterol, glucose and triglycerides. The only exception to this rule was the case of high BP, in which, particularly in men, the process of reduced ability to decrease DBP with age was consistently attenuated or even disappeared.

This investigation was performed on the basis of non-invasive brachial BP measurements.

A limitation of the study was that, primarily, a mercury sphygmomanometer was used for BP measurements, and, then after 3 years follow-up, an OMRON-device was used. However, in the present study, we accounted for this change and verified that it did not modify at all the classification of the overall population. Furthermore, our longitudinal study gave similar results to those previously obtained in the literature. In fact, as in all epidemiological reports, the principal limitation of the investigation was the site of BP measurements: the brachial artery [12]. Indeed, SBP is the most reproducible parameter to determine at the brachial artery site. However as a consequence of the presence of physiological SBP amplification, brachial SBP must be considered as a local parameter, which does not reflect central SBP measurements, except in subjects above 50 years of age without any tachycardia [11,12]. On the other hand, DBP, which is known to involve many errors in its measurement, is not a totally local parameter since its value is almost the same in the entire arterial tree. Brachial DBP may reflect adequately central DBP, and thus might be an index of the perfusion pressure of coronary arteries. In the present study, it is the change in DBP according to age, which was mostly studied. Thus, the errors of DBP measurements during the long-term follow-up might be largely minimized. On the other hand, it is well accepted that the OMRON device that was used for many of the measures in this study is known to predict very adequately the level of CV risk [15]. The D.E.S.I.R. cohort is not a population based study, but from a general French population; we believe these 
results can be generalised to the population, taking into account the characteristics of the French Social Security System.

The principal result of this investigation was obtained from the calculation of the mean change of SBP and DBP per unit year (ie. the rate of change) during the follow-up. Whereas the mean values of SBP and DBP both increased across the different age ranges, the rates of changes of SBP and DBP per year were strikingly dissociated. Across the age ranges, this change increased markedly with age for SBP but markedly decreased with age for DBP (Fig. 3A and 3B). The mathematical model was curvilinear for $\triangle \mathrm{DBP}$ with age, the maximum value being observed around 45 years and it then fell progressively for the higher ages. This evolution suggests an active process relating the reduction of DBP to vascular aging. This aspect differs from that of SBP but occurred similarly in men and women and was independent of traditional CV risk factors such as hypercholesterolemia, glycaemic status, BMI. Note that in the past, many studies have shown that the mean value of DBP decreased with age, but not the rate of change per unit age [8-12]. However, this decrease in the mean value of DBP with age before 55 years of age and was not observed in the present study because the cohort had only a very small geriatric population at inclusion.

In the present study, the increase in the mean values of SBP and DBP with age was shifted toward higher values of SBP and DBP when studied by strata of traditional cardiovascular risk factors (such as higher BMI, diabetes mellitus, and increased cholesterol); the relations however remained parallel. In contrast, the relationship of the SBP or DBP slope with age was influenced exclusively by the presence of high BP, and not by any of the other cardiovascular risk factors. This finding might indicate that the presence of structural changes of arterioles and capillary rarefaction contributes consistently to maintain the elevated values of blood pressure in this population [16]. Further studies are needed to show which factors are responsible for the specific defect in the well-established process of DBP reduction with age.

\section{Perspectives}

This investigation has shown that, in a long-term follow-up, whereas for SBP the rate of change of the relationship increases progressively with age, for DBP the relationship begins to reduce as early as 45 
years. The finding is independent of gender and metabolic disorders but disappears in the presence of hypertension at inclusion, particularly in men. Whether this particularity is influenced by drug treatment is yet difficult to determine and requires further investigations. 


\section{Acknowledgements}

The D.E.S.I.R. Study Group: INSERM-U780: B.Balkau, P.Ducimetière, E.Eschwège; INSERM-U367: F.Alhenc-Gelas; CHUD'ANGERS: Y.Gallois, A.Girault; HOPITAL-BICHAT: F.Fumeron, M.Marre; CENTRES D'EXAMENS DE SANTÉ: Alençon, Angers, Blois, Caen, Chartres, Chateauroux, Cholet, Le Mans, Orléans, Tours; INSTITUT DE RECHERCHE EN MÉDECINE GÉNÉRALE: J.Cogneau; MEDECINS GÉNERALISTES des Départements; INSTITUT INTER-RÉGIONAL POUR LA SANTÉ: C.Born, E.Cacès, M.Cailleau, JG.Moreau, F.Rakotozafy, J.Tichet, S.Vol.

\section{Sources of Funding}

INSERM, CNAMTS, Lilly, Novartis Pharma, Sanofi-Aventis, Association Diabète Risque Vasculaire, Fédération Française de Cardiologie,La Fondation de France, ALFEDIAM, ONIVINS, Ardix Medical, Bayer Diagnostics, Becton Dickinson, Cardionics, Merck Santé, Novo Nordisk, Pierre Fabre, Roche, Topcon.

\section{Disclosures}

None 


\section{References}

1 Hansson L. Are these benefits from any antihypertensive agent additional to blood pressure lowering per se? In: Birkenhäger H, Robertson JI, Zancheti A, ed. Handbook of Hypertension. Amsterdam: Elsevier, 2004, pp 526-540.

2 Staessen JA, Li Y, Thijs L, Wang JG. Changing concepts on the role of blood pressure reduction in cardiovascular prevention. In: Birkenhäger WH, Reid JL ed. Handbook of Hypertension, Vol.23 Arterial Stiffness in Hypertension, Safar ME, O’Rourke MF. Edinburgh: Elsevier, 2006, pp 485-502.

3 Blacher J, Evans A, Arveiller D, Amouyel P, Ferrieres J, Bingham A, Yarnell J, Haas B, Montaye M, Ruidavets JB, Ducimetiere P. Residual coronary risk in men aged 50-59 years treated for hypertension and hyperlipidaemia in the population: the PRIME study. J Hypertens 2004; 22:415-423.

4 Black HR, Yi J-Y. A new classification schema for hypertension based on relative and absolute risk with implications for treatment and reimbursement. Hypertension 1996; 28:719-724.

5 Safar ME, Blacher J, Protogerou A, Achimastos A. Arterial stiffness and central hemodynamics in treated hypertensive subjects according to brachial blood pressure classification. J Hypertens 2008; $26: 130-137$.

6 Vergnaud AC, Protogerou AD, Blacher J, Safar ME. From 'optimal' to 'borderline' blood pressure in subjects under chronic antihypertensive therapy. J Hypertens 2008; 26:138-144.

7 Balkau B, Vernay M, Mhamdi L, Novak M, Arondel D, Vol S, Tichet J, Eschwege E, The D.E.S.I.R. Study Group. The incidence and persistence of the NCEP (National Cholesterol Education Program) metabolic syndrome. The French D.E.S.I.R. study. Diabetes Metab 2003; 29:526-532.

8 Kannel WB, Gordon T, Schwartz MJ. Systolic versus diastolic blood pressure and risk of coronary heart disease: The Framingham Study. Am J Cardiol 1971; 27:335-346.

9 Kannel WB. Blood pressure as a cardiovascular risk factor: Prevention and treatment. JAMA 1996; 275:1571-1576.

10 Stamler J, Neaton JD, Wentworth DN. Blood pressure (systolic and diastolic) and risk of fatal coronary heart disease. Hypertension 1989; 13:I2-I12. 
11 Franklin SS, Gustin IV W, Wong ND, Larson MG, Weber MA, Kannel WB, Levy D. Hemodynamic patterns of age-related changes in blood pressure. Circulation 1997; 96:308-315.

12 Safar ME, Smulyan H. Systolic versus diastolic blood pressure: In Handbook of Hypertension Bulpitt CJ ed. Elsevier Science BV 2000, Amsterdam, pp 73-85.

13 O’Brien E, Mee F, Atkins N, Thomas M. Evaluation of three devices for self-measurement of blood pressure according to the revised British Hypertension Society Protocol: the Omron HEM-705CP, Philips HP5332, and Nissei DS-175. Blood Pressure Monitoring 1996; 1:55-81.

14 Executive Summary of the Third Report of the National Cholesterol Education Program (NCEP) Expert Panel on Detection, Evaluation, and Treatment of High Blood Cholesterol in Adults (Adult Treatment Panel III). JAMA 2001; 285:2486-2497.

15 Bobrie G, Chatellier G, Genes N, Clerson P, Vaur L, Vaisse B, Menard J, Maillion JM. Cardiovascular prognosis of "masked hypertension" detected by blood pressure self-measurement in elderly treated hypertensive patients. JAMA 2004; 29:1342-1349.

16 Izzard AZ, Rizzoni D, Agabiti-Rosei E, Heagerty AM. Small artery structure and hypertension: adaptive changes and target organ damage. J Hypertens 2005; 23:247-250. 


\section{Figure legends}

Fig. 1A. Mean values of systolic blood pressure (SBP) $\mathrm{mmHg}$ by age (5 years), and sex: points indicate observed mean SBP by age class and the lines are the best-fit regressions; both the slope and the intercept differ significantly $(P<0.0001)$ between men and women.

Fig. 1B. Mean values of diastolic blood pressure (DBP) $\mathrm{mmHg}$ by age ( 5 years), and sex: points indicate observed mean DBP by age class with the lines are the best-fit regressions; both the slope and the intercept differ significantly $(P<0.006,0.001$ respectively) between men and women.

Fig. 2A. Mean values of systolic blood pressure (SBP) $\mathrm{mmHg}$ by age and sex, according to strata of blood pressure at inclusion. The slope and the intercept differ significantly between the strata for both men and women.

Fig. 2B. Mean values of diastolic blood pressure (DBP) $\mathrm{mmHg}$ by age and sex. Only the intercepts differ significantly between the strata, for both men and women.

Fig. 3A. Mean change per year $(\triangle \mathrm{SBP}) \mathrm{mmHg}$ by age ( 5 years), and sex: points indicate observed mean changes per year by age class with the lines as the best-fit regressions; intercepts differed significantly $(P=0.0001)$ but identical curvature.

Fig. 3B. Mean change per year $(\triangle \mathrm{DBP}) \mathrm{mmHg}$ by age (5 years), and sex: points indicate observed mean changes per year by age class with the lines as the best-fit regressions; relations are identical for men and women. 
Table 1. Characteristics [mean, (standard deviation) or $\mathrm{n}(\%)$ ] of the men and women at inclusion in the study, and the evolution of the parameters per year, assuming a linear increase.

\begin{tabular}{|c|c|c|c|}
\hline Variables & Men $(n=2,278)$ & Women $(n=2,314)$ & P-value \\
\hline \multicolumn{4}{|l|}{ Baseline levels: } \\
\hline$\overline{\text { Age (years) }}$ & $47.1(10.0)$ & $47.1(10.0)$ & 0.8 \\
\hline BMI $\left(\mathrm{kg} / \mathrm{m}^{2}\right)$ & $25.4(3.3)$ & $24.0(4.0)$ & $<0.0001$ \\
\hline Weight (kg) & $75.8(10.7)$ & $61.1(10.3)$ & $<0.0001$ \\
\hline Height (cm) & $172.6(6.5)$ & $159.6(6.0)$ & $<0.0001$ \\
\hline Waist circumference $(\mathrm{cm})$ & $89.7(9.4)$ & $77.1(10.2)$ & $<0.0001$ \\
\hline Systolic blood pressure $(\mathrm{mmHg})$ & $134.5(14.8)$ & $127.8(15.6)$ & $<0.0001$ \\
\hline Diastolic blood pressure (mmHg) & $82.1(9.5)$ & $77.6(9.0)$ & $<0.0001$ \\
\hline Treated for hypertension & $234(10 \%)$ & $275(12 \%)$ & 0.08 \\
\hline Beta blockers & $94(40 \%)$ & $140(51 \%)$ & 0.01 \\
\hline ACE & $102(44 \%)$ & $69(25 \%)$ & $<0.0001$ \\
\hline Diuretics & $65(28 \%)$ & $96(35 \%)$ & 0.08 \\
\hline Calcium channel blockers & $63(27 \%)$ & $43(16 \%)$ & 0.002 \\
\hline Heart rate (beats per min) & $66.4(10.3)$ & $68.2(9.5)$ & $<0.0001$ \\
\hline Fasting glucose (mmol/1) & $5.57(0.86)$ & $5.13(0.76)$ & $<0.0001$ \\
\hline Cholesterol (mmol/1) & $5.85(1.01)$ & $5.62(0.97)$ & $<0.0001$ \\
\hline HDL-cholesterol (mmol/1) & $1.48(0.38)$ & $1.78(0.42)$ & $<0.0001$ \\
\hline Triglycerides $(\mathrm{mmol} / \mathrm{l})$ & $1.37(1.35)$ & $0.97(0.54)$ & $<0.0001$ \\
\hline Smoking (n, \%) & $616(27 \%)$ & $335(14 \%)$ & $<0.0001$ \\
\hline Alcohol intake (g/day) & $25.2(24.8)$ & $7.3(11.4)$ & $<0.0001$ \\
\hline Postmenopausal (n,\%) & & $878(40 \%)$ & \\
\hline Hormonal replacement therapy $(\mathrm{n}, \%)$ & & $853(38 \%)$ & \\
\hline \multicolumn{4}{|l|}{ Change per year in: } \\
\hline $\mathrm{BMI}\left(\mathrm{kg} / \mathrm{m}^{2}\right)$ & $0.11(0.28)$ & $0.15(0.32)$ & $<0.0001$ \\
\hline Weight $(\mathrm{kg})$ & $0.27(0.82)$ & $0.32(0.77)$ & 0.06 \\
\hline Waist circumference $(\mathrm{cm})$ & $0.32(0.93)$ & $0.45(0.99)$ & $<0.0001$ \\
\hline Systolic blood pressure (mmHg) & $0.94(2.49)$ & $0.53(2.28)$ & $<0.0001$ \\
\hline Diastolic blood pressure $(\mathrm{mmHg})$ & $0.27(1.59)$ & $0.19(1.43)$ & 0.09 \\
\hline Heart rate (beats per min) & $-0.22(1.63)$ & $-0.18(1.57)$ & 0.3 \\
\hline Fasting glucose $(\mathrm{mmol} / \mathrm{l})$ & $0.001(0.13)$ & $-0.002(0.10)$ & 0.4 \\
\hline Cholesterol (mmol/1) & $-0.02(0.14)$ & $0.01(0.13)$ & $<0.0001$ \\
\hline HDL-cholesterol (mmol/l) & $-0.01(0.04)$ & $-0.01(0.05)$ & 0.0002 \\
\hline Triglycerides (mmol/l) & $-0.001(0.25)$ & $0.01(0.08)$ & 0.03 \\
\hline Alcohol intake (g/day) & $-0.38(3.30)$ & $-0.01(1.43)$ & $<0.0001$ \\
\hline
\end{tabular}


TABLE 2. Equations for mean systolic and diastolic blood pressure (mmHg), according to age for men and women, by strata of cardio-metabolic risk factors. Abbreviations: see text.

\begin{tabular}{|c|c|c|c|c|c|}
\hline & & $\begin{array}{l}\text { SBP } \\
\text { men }\end{array}$ & women & $\begin{array}{l}\text { DBP } \\
\text { men }\end{array}$ & women \\
\hline General relation & & $114+0.42$ age & $96+0.66$ age & $65+0.53$ age -0.0033 age $^{2}$ & $57+0.60$ age -0.0033 age $^{2}$ \\
\hline BMI & $\begin{array}{l}<25 \mathrm{~kg} / \mathrm{m}^{2} \\
\geq 25 \mathrm{~kg} / \mathrm{m}^{2}\end{array}$ & $\begin{array}{l}115+0.36 \text { age } \\
120+0.36 \text { age* }\end{array}$ & $\begin{array}{l}97+0.60 \text { age } \\
103+0.60 \text { age* }\end{array}$ & $\begin{array}{l}72+0.17 \text { age } \\
75+0.17 \text { age* }^{*}\end{array}$ & $\begin{array}{l}56+0.63 \text { age }-0.0040 \text { age }^{2} \\
59+0.63 \text { age }-0.0040 \text { age }^{2 *}\end{array}$ \\
\hline Blood pressure & $\begin{array}{l}\mathrm{SBP} \text { and } \mathrm{DBP}<130 / 85 \mathrm{mmHg} \\
\mathrm{SBP} \text { or } \mathrm{DBP} \geq 130 / 85 \mathrm{mmHg}\end{array}$ & $\begin{array}{l}117+0.051 \text { age } \\
126+0.31 \text { age }^{* *}\end{array}$ & $\begin{array}{l}109+0.17 \text { age } \\
122+0.35 \text { age }^{* *}\end{array}$ & $\begin{array}{l}69+0.12 \text { age } \\
80+0.12 \text { age* }\end{array}$ & $\begin{array}{l}58+0.58 \text { age }-0.0052 \text { age }^{2} \\
68+0.58 \text { age }-0.0052 \text { age }^{2 *}\end{array}$ \\
\hline Smoking & $\begin{array}{l}\text { non-smoker } \\
\text { current }\end{array}$ & $\begin{array}{l}114+0.42 \text { age } \\
114+0.42 \text { age }\end{array}$ & $\begin{array}{l}96+0.67 \text { age } \\
96+0.67 \text { age }\end{array}$ & $\begin{array}{l}72+0.21 \text { age } \\
72+0.21 \text { age }\end{array}$ & $\begin{array}{l}57+0.61 \text { age }-0.0036 \text { age }^{2} \\
56+0.61 \text { age }-0.0036 \text { age }^{2 *}\end{array}$ \\
\hline Cholesterol & $\begin{array}{l}\leq 5.7 \mathrm{mmol} / 1 \\
>5.7 \mathrm{mmol} / 1\end{array}$ & $\begin{array}{l}114+0.40 \text { age } \\
117+0.40 \text { age* }\end{array}$ & $\begin{array}{l}97+0.64 \text { age } \\
99+0.64 \text { age* }\end{array}$ & $\begin{array}{l}72+0.20 \text { age } \\
74+0.20 \text { age* }\end{array}$ & $\begin{array}{l}56+0.64 \text { age }-0.0039 \text { age }^{2} \\
57+0.64 \text { age }-0.0039 \text { age }^{2 *}\end{array}$ \\
\hline Glucose status & $\begin{array}{l}\text { normal } \\
\text { impaired fasting glucose } \\
\text { diabetic }\end{array}$ & $\begin{array}{l}116+0.38 \text { age } \\
120+0.38 \text { age } \\
126+0.38 \text { age* }\end{array}$ & $\begin{array}{l}97+0.65 \text { age } \\
101+0.65 \text { age } \\
101+0.65 \text { age* }\end{array}$ & $\begin{array}{l}73+0.18 \text { age } \\
76+0.18 \text { age } \\
79+0.18 \text { age* }\end{array}$ & $\begin{array}{l}56+0.65 \text { age }-0.0040 \text { age }^{2} \\
59+0.65 \text { age }-0.0040 \text { age }^{2} \\
59+0.65 \text { age }-0.0040 \text { age }^{2 *}\end{array}$ \\
\hline $\begin{array}{l}\text { Anti- } \\
\text { hypertensive } \\
\text { treatment }\end{array}$ & $\begin{array}{l}\text { non-treated } \\
\text { treated }\end{array}$ & $\begin{array}{l}117+0.34 \text { age } \\
127+0.34 \text { age* }\end{array}$ & $\begin{array}{l}99+0.59 \text { age } \\
108+0.59 \text { age* }\end{array}$ & $\begin{array}{l}73+0.18 \text { age } \\
87+0.010 \text { age* }\end{array}$ & $\begin{array}{l}55+0.70 \text { age }-0.0047 \mathrm{age}^{2} \\
59+0.70 \text { age }-0.0047 \mathrm{age}^{2 *}\end{array}$ \\
\hline $\begin{array}{l}\text { Menopausal } \\
\text { status }\end{array}$ & $\begin{array}{l}\text { premenopausal } \\
\text { postmenopausal }\end{array}$ & & $\begin{array}{l}93+0.75 \text { age } \\
91+0.75 \text { age }\end{array}$ & & $\begin{array}{l}56+0.66 \text { age }-0.0040 \text { age }^{2} \\
56+0.66 \text { age }-0.0040 \text { age }^{2}\end{array}$ \\
\hline $\begin{array}{l}\text { Hormonal } \\
\text { replacement } \\
\text { therapy }\end{array}$ & $\begin{array}{l}\text { non treated } \\
\text { treated }\end{array}$ & & $\begin{array}{l}93+0.73 \text { age } \\
101+0.58 \text { age }^{* *}\end{array}$ & & $\begin{array}{l}52+0.76 \text { age }-0.0046 \text { age }^{2} \\
57+0.65 \text { age }-0.0046 \text { age }^{2 * *}\end{array}$ \\
\hline
\end{tabular}

*intercepts differ significantly between the strata of risk factors

** intercepts and age coefficients differ significantly between the strata of risk factors 
TABLE 3. Equations for rates of change of systolic ( $\triangle \mathrm{SBP})$ and diastolic $(\triangle \mathrm{DBP})$ blood pressure (mmHg), according to age for men and women, by strata of metabolic risk factors. Abbreviations: see text.

\begin{tabular}{|c|c|c|c|c|c|}
\hline & & $\begin{array}{l}\text { SBP } \\
\text { men }\end{array}$ & women & $\begin{array}{l}\text { DBP } \\
\text { men }\end{array}$ & women \\
\hline \multicolumn{2}{|l|}{ General relation } & $\begin{array}{l}-2.07+0.10 \text { age } \\
-0.00083 \mathrm{age}^{2}\end{array}$ & $\begin{array}{l}-2.48+0.10 \text { age } \\
-0.00083 \mathrm{age}^{2}\end{array}$ & $\begin{array}{l}-1.02+0.068 \text { age } \\
-0.00084 \text { age }^{2}\end{array}$ & $\begin{array}{l}-1.02+0.068 \text { age } \\
-0.00084 \mathrm{age}^{2}\end{array}$ \\
\hline \multirow[t]{2}{*}{ BMI } & $<25 \mathrm{~kg} / \mathrm{m}^{2}$ & $-0.61+0.033$ age & $-0.41+0.020$ age & $\begin{array}{l}-2.20+0.12 \text { age }- \\
0.0013 \text { age }^{2}\end{array}$ & $0.87-0.014$ age \\
\hline & $\geq 25 \mathrm{~kg} / \mathrm{m}^{2}$ & $-0.61+0.033$ age & $-0.41+0.020$ age & $\begin{array}{l}-2.20+0.12 \text { age }- \\
0.0013 \mathrm{age}^{2}\end{array}$ & $0.87-0.014$ age \\
\hline \multirow[t]{2}{*}{ Blood pressure } & $\mathrm{SBP}$ and $\mathrm{DBP}<130 / 85 \mathrm{mmHg}$ & $-0.40+0.040$ age & $-0.79+0.037$ age & $\begin{array}{l}-1.97+0.12 \text { age }- \\
0.0013 \text { age }^{2}\end{array}$ & $0.64-0.0043$ age \\
\hline & $\mathrm{SBP}$ or $\mathrm{DBP} \geq 130 / 85 \mathrm{mmHg}$ & $-1.22+0.040$ age* & $-1.68+0.037$ age* & $\begin{array}{l}-2.43+0.12 \text { age }- \\
0.0013 \text { age }^{2 *}\end{array}$ & $0.11-0.0043$ age* \\
\hline \multirow[t]{2}{*}{ Smoking } & non & $-0.61+0.033$ age & $-0.41+0.020$ age & $\begin{array}{l}-2.20+0.12 \text { age }- \\
0.0013 \text { age }^{2}\end{array}$ & $0.87-0.014$ age \\
\hline & current & $-0.61+0.033$ age & $-0.41+0.020$ age & $\begin{array}{l}-2.20+0.12 \text { age }- \\
0.0013 \text { age }^{2}\end{array}$ & $0.87-0.014$ age \\
\hline \multirow[t]{2}{*}{ Cholesterol } & $\leq 5.7 \mathrm{mmol} / 1$ & $-0.61+0.033$ age & $-0.50+0.024$ age & $\begin{array}{l}-2.20+0.12 \text { age }- \\
0.0013 \text { age }^{2}\end{array}$ & $0.81-0.011$ age \\
\hline & $>5.7 \mathrm{mmol} / \mathrm{l}$ & $-0.61+0.033$ age & $-0.76+0.024$ age* & $\begin{array}{l}-2.20+0.12 \text { age }- \\
0.0013 \mathrm{age}^{2}\end{array}$ & $0.63-0.011$ age* \\
\hline \multirow[t]{3}{*}{ Glucose status } & normal & $-0.87+0.037$ age & $-1.20+0.033$ age & $\begin{array}{l}-3.84+0.18 \text { age }- \\
0.0020 \mathrm{age}^{2}\end{array}$ & $0.72-0.012$ age \\
\hline & impaired fasting glucose & $-0.87+0.037$ age & $-1.20+0.033$ age & $\begin{array}{l}-3.84+0.18 \text { age }- \\
0.0020 \text { age }^{2}\end{array}$ & $0.72-0.012$ age \\
\hline & diabetic & $-0.87+0.037$ age & $-1.20+0.033$ age & $\begin{array}{l}-3.84+0.18 \text { age }- \\
0.0020 \mathrm{age}^{2}\end{array}$ & $0.72-0.012$ age \\
\hline \multirow{2}{*}{$\begin{array}{l}\text { Anti-hypertensive } \\
\text { treatment }\end{array}$} & non-treated & $-0.61+0.033$ age & $-0.58+0.025$ age & $\begin{array}{l}-2.20+0.12 \text { age }- \\
0.0013 \text { age }^{2}\end{array}$ & $0.76-0.011$ age \\
\hline & treated & $-0.61+0.033$ age & $-1.19+0.025$ age* & $-2.20+0.12$ age - & $0.40-0.011 \mathrm{age}^{*}$ \\
\hline
\end{tabular}


Menopausal status premenopausal

postmenopa treated

Hormonal

replacement therapy
$-0.41+0.020$ age

$-0.41+0.020$ age

$-0.41+0.020$ age $-0.41+0.020$ age
$0.87-0.014$ age

$0.87-0.014$ age

$0.87-0.014$ age $0.87-0.014$ age

*intercepts differ significantly between the strata of risk factors 


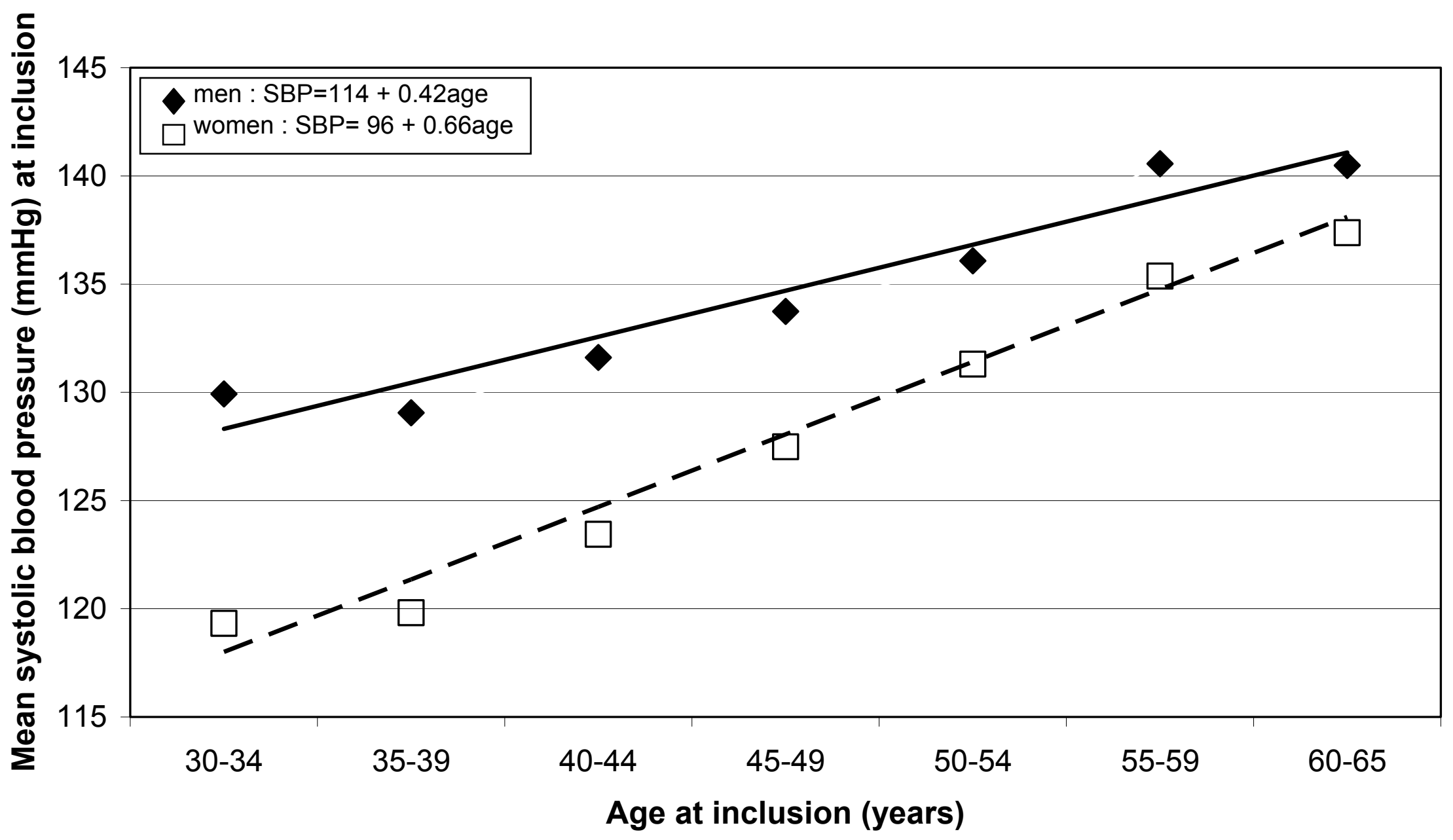




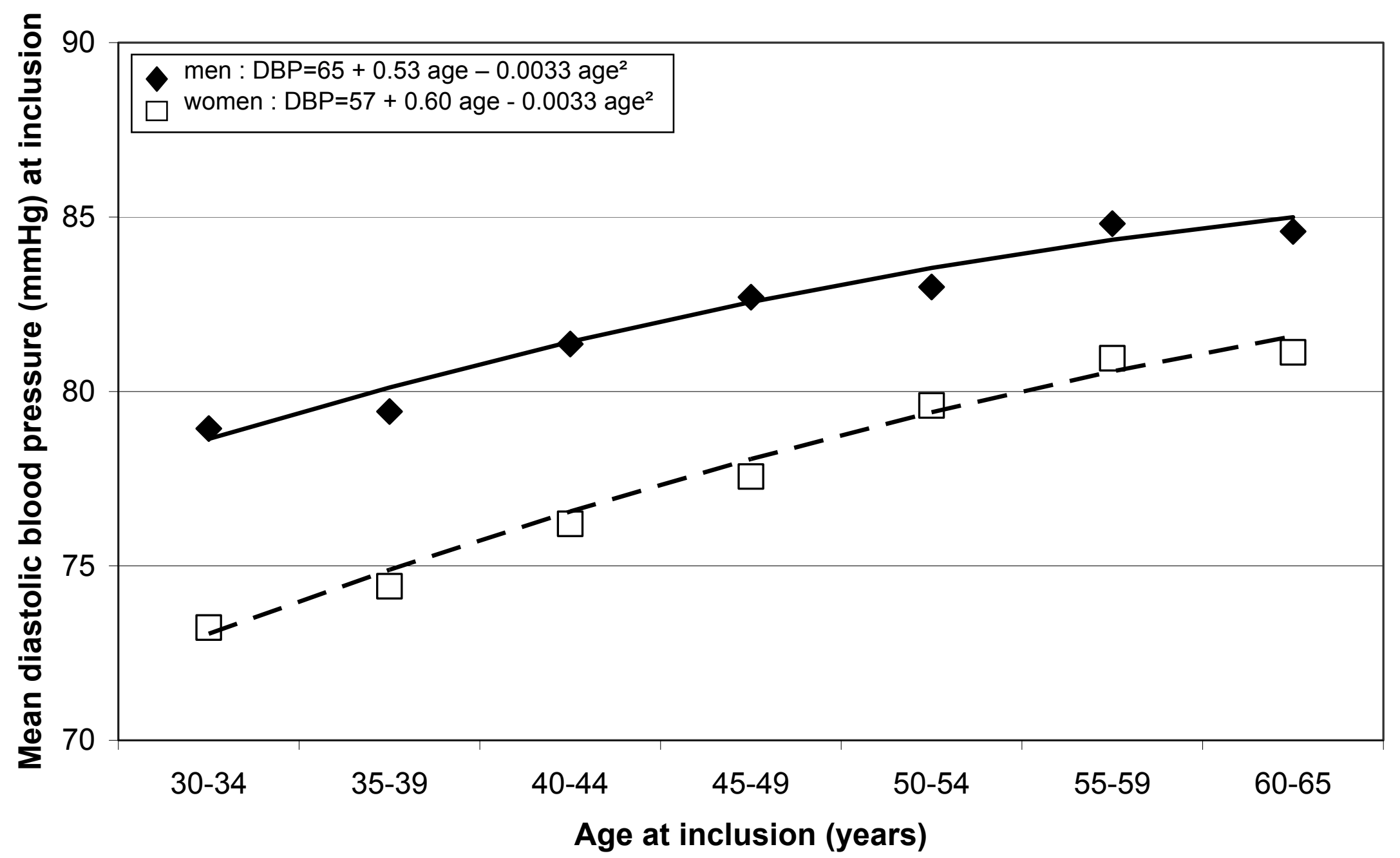


Figure 2A

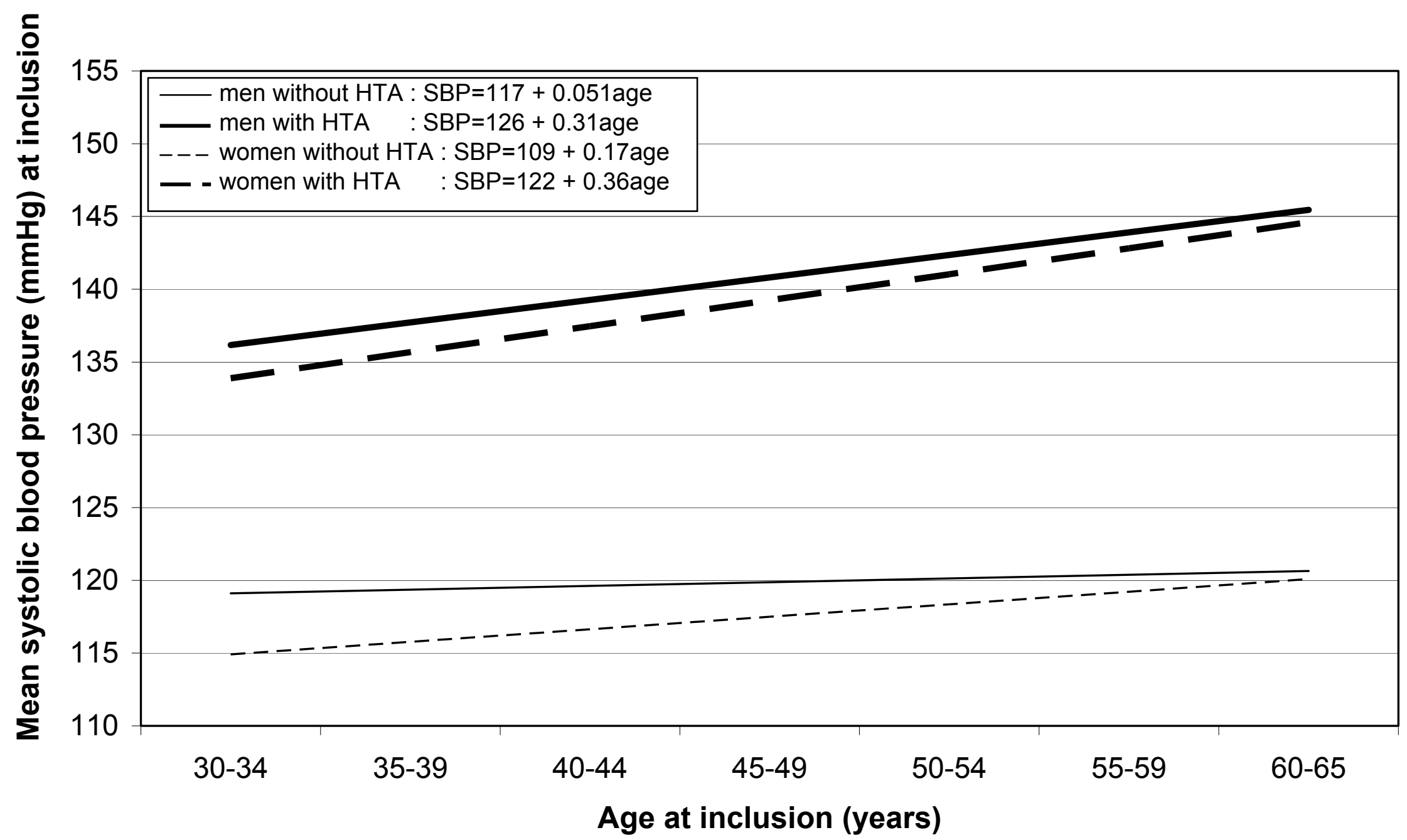




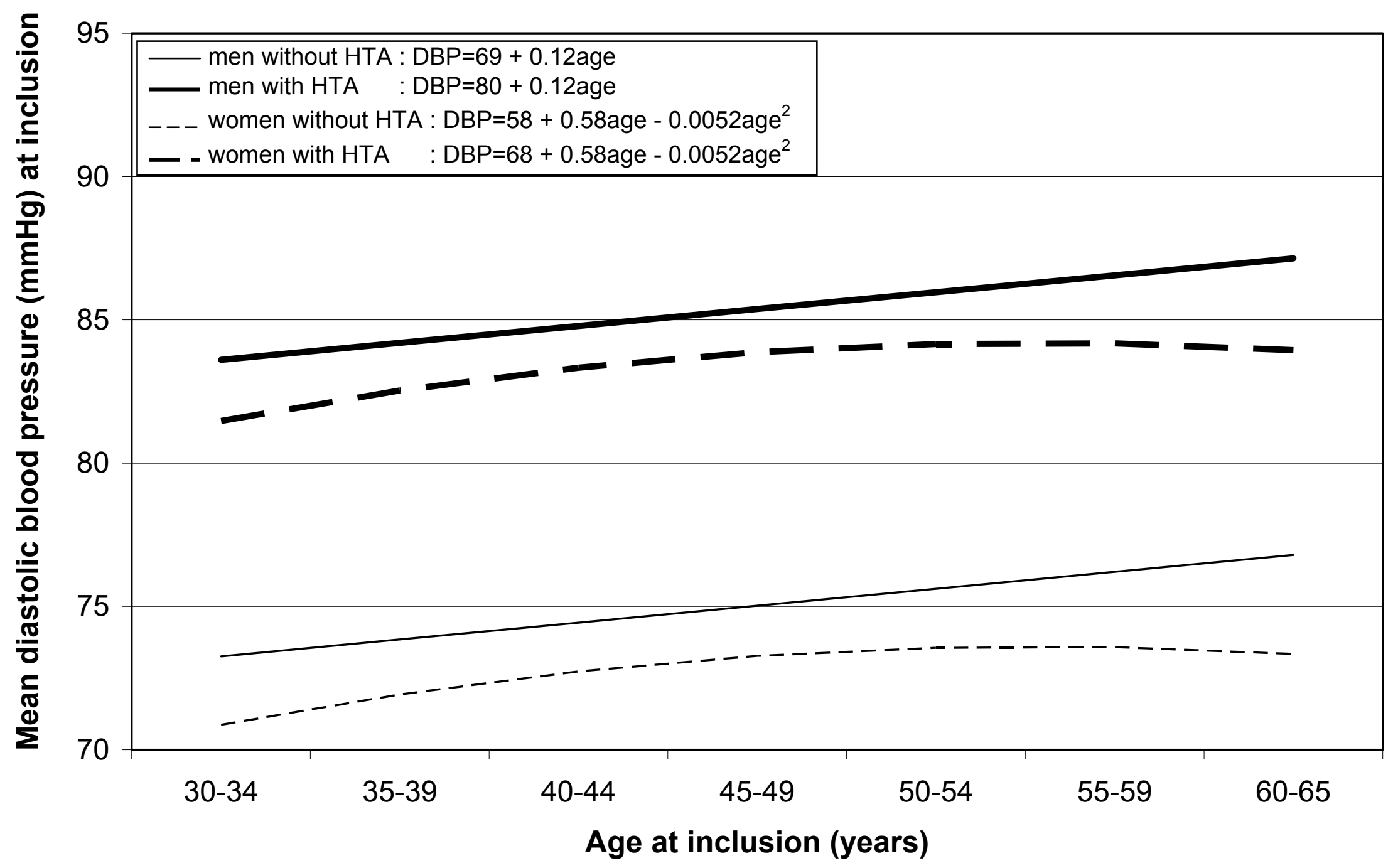


Figure 3A

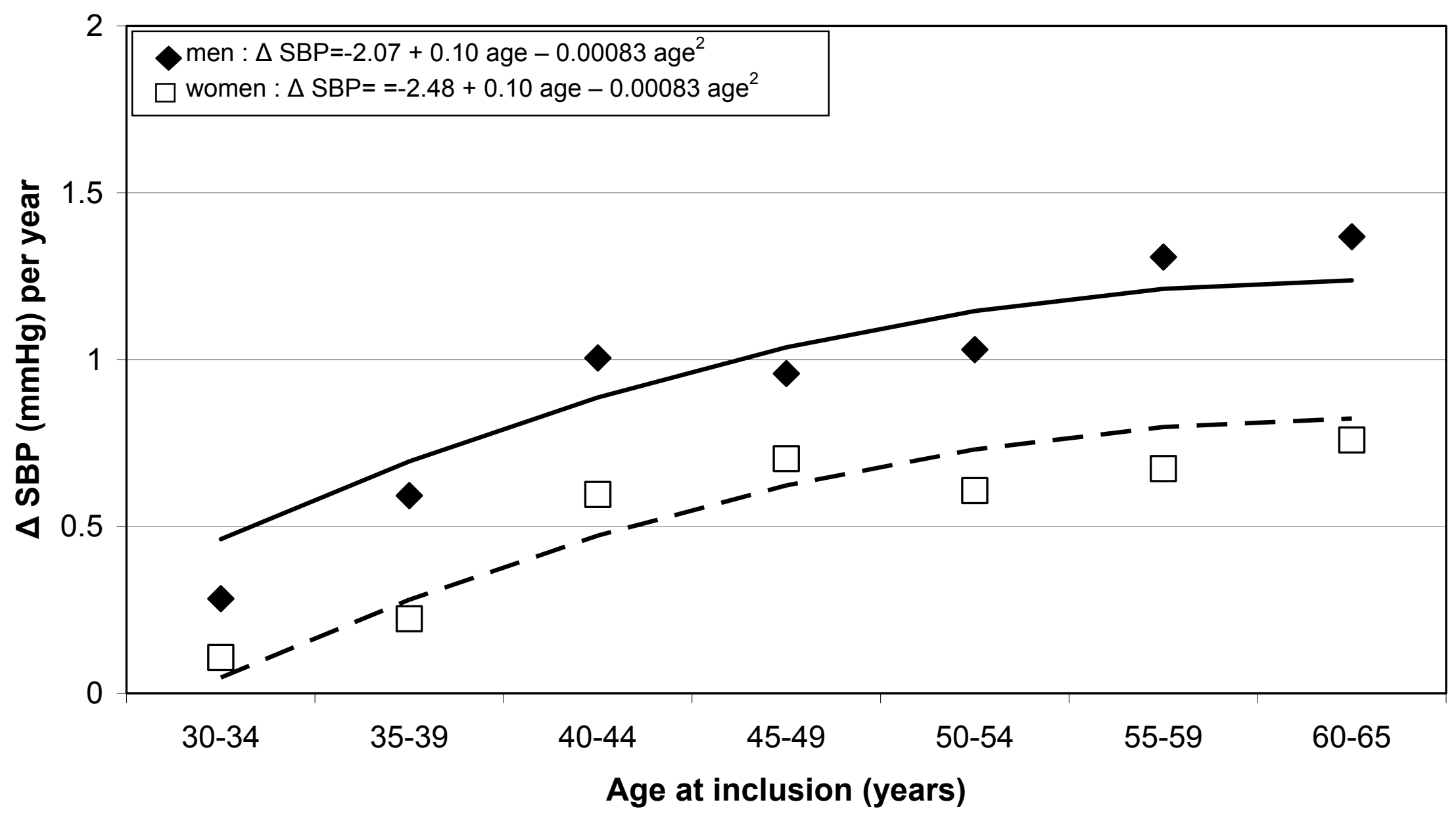




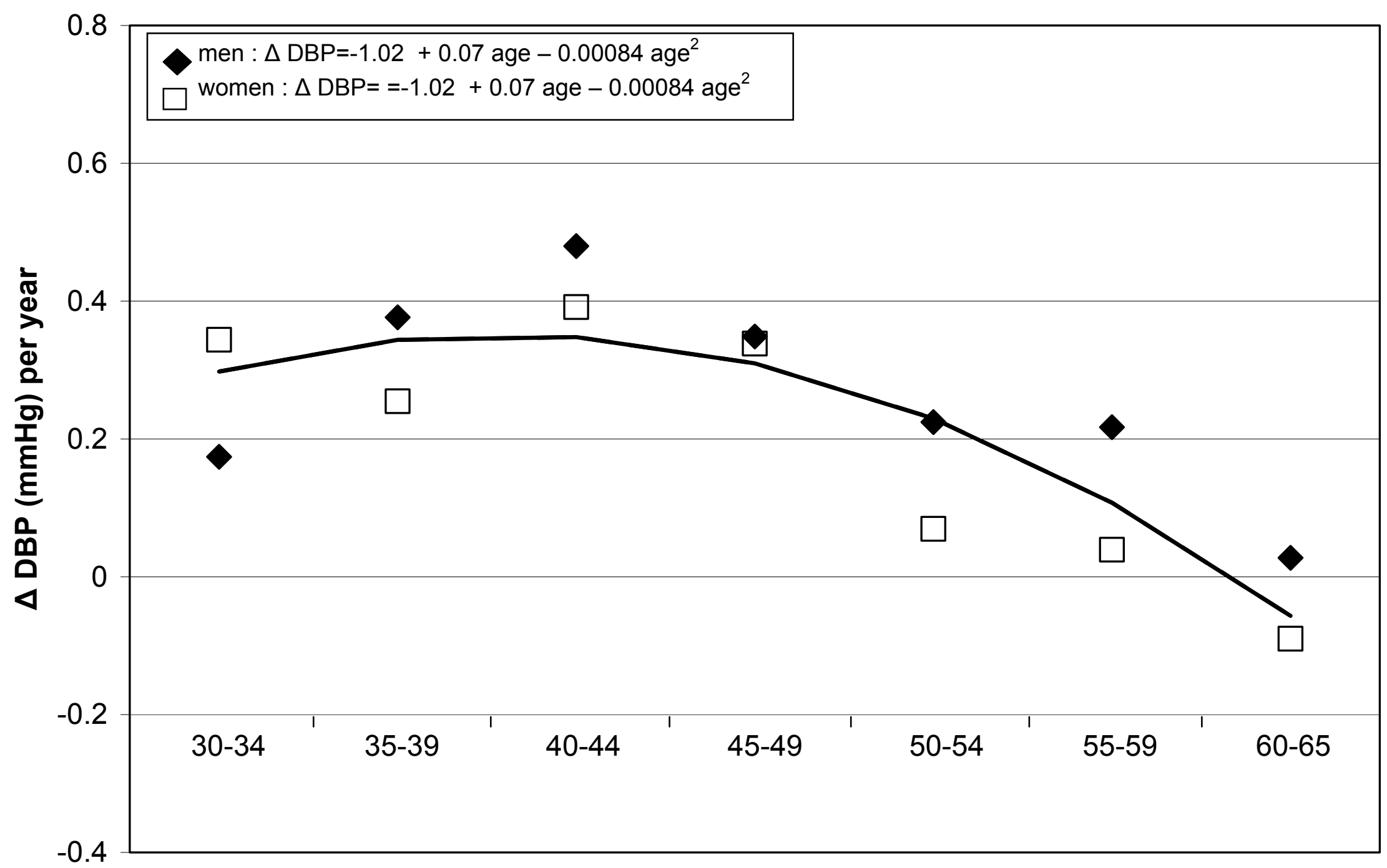

Age at inclusion (years) 